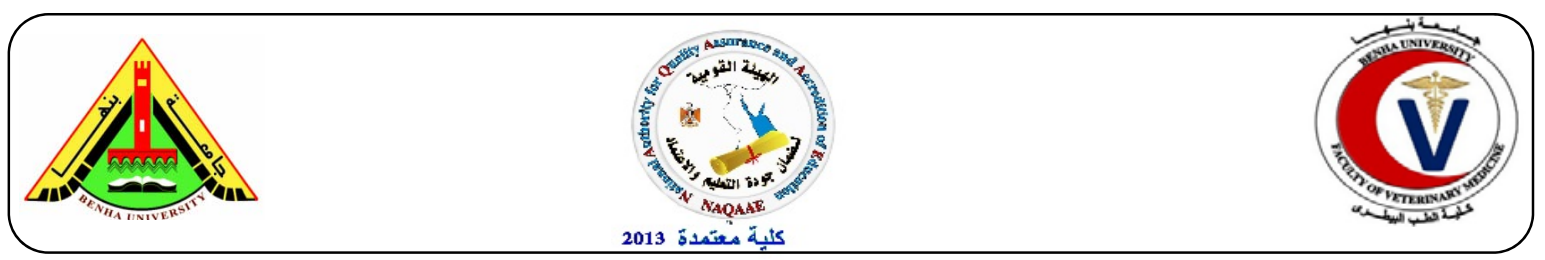

\title{
Effects of Sunflower Meals Inclusion on Performance and Some Haematological Parameters in Broiler chicks
}

\author{
Nasser E. Khedr, Tahia E. Ahmed, Fatma Ragab \\ Department of Nutrition and Clinical Nutrition, Faculty of Veterinary Medicine, Benha University
}

\begin{abstract}
A B S T R A C T
A total of two hundred twenty five one-day-old Indian river broiler chicks (IR) were distributed into five different treatment groups (A, B, C, D and E), of three replicates (15 chicks / replicate). The chicks in control group (A) were fed control diet with $\beta$ - mannanase $\left(\right.$ Hemicell ${ }^{\circledR}$ ), groups B and $C$ were fed diets containing SFM (2.5 and 5\%, respectively) without $\beta$-mannanase (Hemicell ${ }^{\mathbb{R}}$ ). While groups D and $\mathrm{E}$ were fed diets containing SFM (2.5 and 5\%, respectively) with $\beta$-mannanase (Hemicell ${ }^{\circledR}$ ). Effects of inclusion Sunflower meals with or without $\beta$-mannanase $\left(\right.$ Hemicell $\left.{ }^{\circledR}\right)$ on performance showed that groups containing Sunflower meals $2.5 \%$ with or without enzyme show improvements than other groups. Erythrogram profile showed a significant $(p \leq 0.05)$ difference between control group and other groups in $\mathrm{Hb}, \mathrm{RBCs}, \mathrm{PCV}$ and MCV levels, while there was a significant $(p \leq 0.05)$ increase in $\mathrm{MCH}$ and $\mathrm{MCHC}$ in group $\mathrm{E}\left(\mathrm{SFM} 5 \%+\right.$ Hemicell $\left.^{\circledR}\right)$ when compared with other groups. Leukogram showed nonsignificant changes between control group and other groups. It was concluded that inclusion of sunflower meals $2.5 \%$ had a positive role in improvement final body weight changes and final body weight gain. Partial replacement diet with sunflower meals $\left(2.5\right.$ and $5 \%$ with or without Hemicell $\left.{ }^{\circledR}\right)$ did not induce side effects on hematological parameters.
\end{abstract}

Keywords: Broiler chicks, Sunflower meals, $\beta$-mannanase $\left(\right.$ Hemicell $\left.{ }^{\circledR}\right)$, Chick performance and hematological profile.

(http://www.bvmj.bu.edu.eg)

(BVMJ-30(1): 331-340, 2016)

\section{INTRODUCTION}

$\mathrm{S}$ unflower meal is a by-product of sunflower oil industry. However, replacement of soybean meal (SBM) with SFM may affect dietary inclusions of essential amino acids, so synthetic lysine may need to be increased. The high levels of SFM in poultry diets can be used successfully with appropriate diet formulation adjustments for energy and amino acids particularly lysine and methionine (Mahmoud et al., 2015). Crude protein content of SFM is 29 to $45 \%$ depending on the dehulling and oil extraction process which has an inverse relation with its crude fiber (32 to $14 \%$ ) contents (Mushtaq et al., 2006). SFM contain high levels of non-starch polysaccharides (NSP) and phytates it would be useful to investigate the effect of enzyme supplementation on diets containing these ingredients. The addition of exogenous enzymes (phytase, hemicellulase, cellulase, pectinase, protease, lipase, $\beta$-glucanase, etc.) offers a number of creative possibilities for breakdown and "liberation" of these nutrients, their easier digestion and absorption, and thus development of new nutritional standards and new diets formulation (Acamovic, 2001). The present work was conducted to evaluate the use of different levels of sunflower meal as a protein supplement for broiler with or without enzyme $\beta$-mannanase (Hemicell ${ }^{\circledR}$ ) and their effects on performance and some hematological parameters. 


\section{MATERIAL AND METHODS}

\subsection{Birds, housing and management}

The present study was carried out using 225 one-day old Indian river broiler chicks. The chicks reared at suitable environment using the bird house at the Faculty of Veterinary Medicine, Benha University. The chicks were randomly allocated into 5 groups, each group contain 3 replicates of 15 chicks each reared on a deep litter system. The different groups were maintained under good ventilation and continuous lightening program. Feed and water were offered adlibitum. All birds were systematically vaccinated against Newcastle and other needed prophylactic measures.

\subsection{Diets}

The chicks were distributed in to 5 treatment groups (A, B, C, D and E). A considered as control group and fed basal diet with $\beta$ - mannanase (Hemicell $\left.{ }^{\circledR}\right)$, group $\mathrm{B}$ and $\mathrm{C}$ were fed diets containing SFM (2.5, 5\%, respectively) without $\beta$ mannanase (Hemicell $\AA$ ). While groups $D$ and $E$ were fed on diets containing SFM $(2.5,5 \%$, respectively) with $\beta$-mannanase (Hemicell®). Nutrient requirements with calculated analysis were determined according National Research Council NRC, (1994) as described in Tables 1, 2 and 3. The chemical composition of the sunflower meal used in this study was as follows: Dry matter (90.97\%), Moisture (9.03\%), Crude protein $(34.58 \%)$, Ether extracts $(1.05 \%)$, Crude fiber (11.65\%) ash $(5.603 \%)$ and Nitrogen-free extract (17.07\%). The estimated Metabolizable energy of the used Sunflower meal was $(1688 \mathrm{kcal} / \mathrm{kg})$.

\subsection{Experimental procedure}

Chicks had free access of feed and water and were vaccinated according to the sanitary programs. Feed consumption was recorded for each treatment. Live body weight in grams was measured for all birds at the beginning of the experiment and then weekly. At the end of experiment (35 days of age), 5 birds were chosen randomly from each group and fasted 12 hours for measurements of some hematological parameters.

\subsection{Hematological parameters}

Blood samples were collected by needle from jugular vein from chicks of different dietary supplemented groups then withdrawing the blood into container with proper anticoagulant ethylene diamine tetra-acetic acid (EDETA). Hematological studies included erythrogram and leukogram through manual counting.

\subsection{Erythrogram included: -}

Hemoglobin $(\mathrm{Hb})$ concentration, packed cell volume (PCV), RBCs count, mean corpuscular volume (MCV), mean corpuscular hemoglobin $(\mathrm{MCH})$, and mean corpuscular hemoglobin concentration (MCHC).

\subsection{Leukogram included: -}

Total leukocytic count (TLC) and differential leukocytic count (DLC).

\subsection{Statistical analysis: -}

Data obtained in this study were statistically analyzed for variance ANOVA with confidence limits set at $95 \%$ (Significance at $P \leq 0.05$ probability level) and critical difference as described by (Duncan, SPSS Student Version 10.0.7, June 2000). The results were reported as the mean \pm standard error (SE).

\section{RESULTS}

The effects of inclusion SFM 2.5 and 5\% with or without Hemicell® enzyme on performance of growing broiler chickens are shown in Table(4).

Body weight gain showed non-significant changes between groups. Also, groups B and $\mathrm{D}$ showed high value when compared with other groups. Feed intake in groups (D and E) that received SFM 2.5, 5\% 
Table (1): The ingredients composition (\%) of the starter diets (1- 10 days) of the experimental groups.

\begin{tabular}{|c|c|c|c|c|c|c|}
\hline \multirow{2}{*}{ Ingredients } & \multirow{2}{*}{ Units } & \multicolumn{5}{|c|}{ Experimental Diets } \\
\hline & & A & $\mathrm{B}$ & $\mathrm{C}$ & $\mathrm{D}$ & $\mathrm{E}$ \\
\hline Yellow corn & $\%$ & 52.86 & 49.06 & 48.55 & 50.99 & 49.26 \\
\hline Soybean meal (44\%) & $\%$ & 35 & 33.8 & 31.8 & 35 & 35 \\
\hline Corn gluten meal & $\%$ & 5.7 & 5.5 & 5.5 & 4.5 & 3.3 \\
\hline Sunflower meal & $\%$ & - & 2.5 & 5.00 & 2.5 & 5.00 \\
\hline Vegetable oil & $\%$ & 1.65 & 4.4 & 4.4 & 2.3 & 2.8 \\
\hline Dicalcium phosphate & $\%$ & 1.7 & 1.7 & 1.7 & 1.68 & 1.65 \\
\hline Lime stone & $\%$ & 1.4 & 1.38 & 1.36 & 1.38 & 1.35 \\
\hline Vitamin \&mineral premix* & $\%$ & 0.30 & 0.30 & 0.30 & 0.30 & 0.30 \\
\hline DL - Methionine & $\%$ & 0.31 & 0.31 & 0.3 & 0.31 & 0.31 \\
\hline L - Lysine & $\%$ & 0.28 & 0.29 & 0.33 & 0.26 & 0.24 \\
\hline L - Threonine & $\%$ & 0.15 & 0.15 & 0.16 & 0.15 & 0.15 \\
\hline Sodium chloride & $\%$ & 0.31 & 0.31 & 0.31 & 0.30 & 0.30 \\
\hline Sodium bicarbonate & $\%$ & 0.15 & 0.15 & 0.15 & 0.15 & 0.15 \\
\hline Feed additives & $\%$ & 0.15 & 0.15 & 0.15 & 0.15 & 0.15 \\
\hline Hemicell & $\%$ & 0.035 & - & - & 0.035 & 0.035 \\
\hline Avemix P 5000** & $\%$ & 0.01 & 0.01 & 0.01 & 0.01 & 0.01 \\
\hline Total & $\%$ & 100 & 100 & 100 & 100 & 100 \\
\hline Chemical composition & Units & A & B & $\mathrm{C}$ & $\mathrm{D}$ & $\mathrm{E}$ \\
\hline ME & $\mathrm{Kcal} / \mathrm{Kg}$ & 3049 & 3050 & 3047 & 3053 & 3049 \\
\hline $\mathrm{CP}$ & $\%$ & 22.5 & 22.48 & 22.5 & 22.5 & 22.51 \\
\hline $\mathrm{CF}$ & $\%$ & 3.58 & 3.98 & 4.4 & 4.09 & 4.61 \\
\hline Lysine & $\%$ & 1.35 & 1.35 & 1.35 & 1.35 & 1.35 \\
\hline Methionine & $\%$ & 0.67 & 0.67 & 0.66 & 0.66 & 0.66 \\
\hline Methionine + cysteine & $\%$ & 0.95 & 0.95 & 0.94 & 0.95 & 0.95 \\
\hline Threonine & $\%$ & 0.96 & 0.96 & 0.96 & 0.96 & 0.97 \\
\hline Calcium & $\%$ & 1.06 & 1.06 & 1.05 & 1.05 & 1.04 \\
\hline Available phosphorus & $\%$ & 0.50 & 0.50 & 0.50 & 0.50 & 0.50 \\
\hline Sodium & $\%$ & 0.17 & 0.17 & 0.17 & 0.17 & 0.17 \\
\hline Chloride & $\%$ & 0.23 & 0.22 & 0.22 & 0.22 & 0.22 \\
\hline Potassium & $\%$ & 0.88 & 0.87 & 0.85 & 0.90 & 0.83 \\
\hline
\end{tabular}

*Vitamin-mineral mixture was composed of: Each $3 \mathrm{~kg}$ contain: Vit. A 12000000 IU, vit. D3 2000000 IU, vit. E $10000 \mathrm{mg}$, vit. K3 $2000 \mathrm{mg}$, vit B11000 mg, vit. B2 $5000 \mathrm{mg}$, vit B6 $1500 \mathrm{mg}$, vit. B12 10 $\mathrm{mg}$, Biotin $50 \mathrm{mg}$, pantothenic acid $10000 \mathrm{mg}$, Nicotinic acid $30000 \mathrm{mg}$, Folic acid $1000 \mathrm{mg}$, Manganese $60000 \mathrm{mg}$, Zinc $50000 \mathrm{mg}$, Iron $30000 \mathrm{mg}$, Copper $10000 \mathrm{mg}$, Iodine $1000 \mathrm{mg}$, Selenium $100 \mathrm{mg}$, Cobalt $100 \mathrm{mg}$, carrier (CaCo3) add to $3 \mathrm{~kg}$. **Phytase: - (Avemix P5000) was used as feed additive for poultry at a rate of $0.10 \mathrm{~g} / \mathrm{Kg}$. 
Effects of Sunflower Meals Inclusion on Performance and Some Haematological Parameters in Broiler chicks

Table (2): The ingredients composition (\%) of the grower diets (11-24 days) of the experimental groups.

\begin{tabular}{|c|c|c|c|c|c|c|}
\hline \multirow{2}{*}{ Ingredients } & \multirow{2}{*}{ Units } & \multicolumn{5}{|c|}{ Experimental Diets } \\
\hline & & A & $\mathrm{B}$ & $\mathrm{C}$ & $\mathrm{D}$ & E \\
\hline Yellow corn & $\%$ & 53.66 & 52.46 & 52.04 & 51.82 & 49.96 \\
\hline Soybean meal (44\%) & $\%$ & 35 & 29.7 & 27.6 & 35 & 35 \\
\hline Corn gluten meal & $\%$ & 3.3 & 5.5 & 5.5 & 2.1 & 0.9 \\
\hline Sunflower meal & $\%$ & - & 2.5 & 5.00 & 2.5 & 5.00 \\
\hline Vegetable oil & $\%$ & 4 & 5.7 & 5.7 & 4.6 & 5.2 \\
\hline Dicalcium phosphate & $\%$ & 1.43 & 1.45 & 1.45 & 1.4 & 1.4 \\
\hline Lime stone & $\%$ & 1.16 & 1.15 & 1.15 & 1.15 & 1.15 \\
\hline Vitamin \&mineral premix* & $\%$ & 0.3 & 0.30 & 0.30 & 0.30 & 0.30 \\
\hline DL - Methionine & $\%$ & 0.26 & 0.24 & 0.23 & 0.26 & 0.26 \\
\hline L - Lysine & $\%$ & 0.18 & 0.30 & 0.33 & 0.16 & 0.14 \\
\hline L - Threonine & $\%$ & 0.09 & 0.10 & 0.10 & 0.08 & 0.08 \\
\hline Sodium chloride & $\%$ & 0.30 & 0.30 & 0.30 & 0.30 & 0.30 \\
\hline Sodium bicarbonate & $\%$ & 0.15 & 0.15 & 0.15 & 0.15 & 0.15 \\
\hline Feed additives & $\%$ & 0.15 & 0.15 & 0.15 & 0.15 & 0.15 \\
\hline Hemicell & $\%$ & 0.035 & - & - & 0.035 & 0.035 \\
\hline Avemix P $5000 * *$ & $\%$ & 0.01 & 0.01 & 0.01 & 0.01 & 0.01 \\
\hline Total & $\%$ & 100 & 100 & 100 & 100 & 100 \\
\hline Chemical composition & Units & $\mathrm{A}$ & $\mathrm{B}$ & $\mathrm{C}$ & $\mathrm{D}$ & $\mathrm{E}$ \\
\hline $\mathrm{ME}$ & $\mathrm{Kcal} / \mathrm{Kg}$ & 3174 & 3176 & 3175 & 3175 & 3175 \\
\hline $\mathrm{CP}$ & $\%$ & 21 & 20.98 & 20.97 & 21 & 21 \\
\hline $\mathrm{CF}$ & $\%$ & 3.57 & 3.76 & 4.17 & 4.08 & 4.59 \\
\hline Lysine & $\%$ & 1.25 & 1.25 & 1.25 & 1.25 & 1.25 \\
\hline Methionine & $\%$ & 0.58 & 0.58 & 0.58 & 0.58 & 0.58 \\
\hline Methionine + cysteine & $\%$ & 0.84 & 0.84 & 0.84 & 0.84 & 0.84 \\
\hline Threonine & $\%$ & 0.85 & 0.86 & 0.85 & 0.85 & 0.85 \\
\hline Calcium & $\%$ & 0.91 & 0.90 & 0.91 & 0.90 & 0.90 \\
\hline Available phosphorus & $\%$ & 0.45 & 0.45 & 0.45 & 0.45 & 0.45 \\
\hline Sodium & $\%$ & 0.17 & 0.17 & 0.17 & 0.17 & 0.17 \\
\hline Chloride & $\%$ & 0.22 & 0.22 & 0.22 & 0.22 & 0.22 \\
\hline Potassium & $\%$ & 0.87 & 0.80 & 0.78 & 0.89 & 0.9 \\
\hline
\end{tabular}

*Vitamin-mineral mixture was composed of: Each $3 \mathrm{~kg}$ contain: Vit. A 12000000 IU, vit. D3 2000000 IU, vit. E $10000 \mathrm{mg}$, vit. K3 $2000 \mathrm{mg}$, vit B11000 mg, vit. B2 $5000 \mathrm{mg}$, vit B6 $1500 \mathrm{mg}$, vit. B12 10 $\mathrm{mg}$, Biotin $50 \mathrm{mg}$, pantothenic acid $10000 \mathrm{mg}$, Nicotinic acid $30000 \mathrm{mg}$, Folic acid $1000 \mathrm{mg}$, Manganese $60000 \mathrm{mg}$, Zinc $50000 \mathrm{mg}$, Iron $30000 \mathrm{mg}$, Copper $10000 \mathrm{mg}$, Iodine $1000 \mathrm{mg}$, Selenium $100 \mathrm{mg}$, Cobalt $100 \mathrm{mg}$, carrier (CaCo3) add to $3 \mathrm{~kg}$. **Phytase: - (Avemix P5000) was used as feed additive for poultry at a rate of $0.10 \mathrm{~g} / \mathrm{Kg}$. 
Table (3): The ingredients composition (\%) of the finisher diets (after 24 days ) of the experimental groups:-

\begin{tabular}{|c|c|c|c|c|c|c|}
\hline \multirow{2}{*}{ Ingredients } & \multirow{2}{*}{ Units } & \multicolumn{5}{|c|}{ Experimental Diets } \\
\hline & & A & $\mathrm{B}$ & $\mathrm{C}$ & $\mathrm{D}$ & $\mathrm{E}$ \\
\hline Yellow corn & $\%$ & 56.4 & 57.81 & 57.34 & 55.92 & 55.4 \\
\hline Soybean meal (44\%) & $\%$ & 34.8 & 25.6 & 23.5 & 32.7 & 30.7 \\
\hline Corn gluten meal & $\%$ & - & 4.5 & 4.5 & - & - \\
\hline Sunflower meal & $\%$ & - & 2.5 & 5.00 & 2.5 & 5.00 \\
\hline Vegetable oil & $\%$ & 5.1 & 5.7 & 5.8 & 5.2 & 5.2 \\
\hline Dicalcium phosphate & $\%$ & 1.27 & 1.30 & 1.30 & 1.28 & 1.28 \\
\hline Lime stone & $\%$ & 1.15 & 1.15 & 1.10 & 1.10 & 1.10 \\
\hline Vitamin \&mineral premix* & $\%$ & 0.3 & 0.30 & 0.30 & 0.30 & 0.30 \\
\hline DL - Methionine & $\%$ & 0.26 & 0.21 & 0.20 & 0.25 & 0.24 \\
\hline L - Lysine & $\%$ & 0.02 & 0.25 & 0.28 & 0.06 & 0.09 \\
\hline L - Threonine & $\%$ & 0.06 & 0.08 & 0.08 & 0.06 & 0.06 \\
\hline Sodium chloride & $\%$ & 0.30 & 0.30 & 0.3 & 0.3 & 0.3 \\
\hline Sodium bicarbonate & $\%$ & 0.15 & 0.15 & 0.15 & 0.15 & 0.15 \\
\hline Feed additives & $\%$ & 0.15 & 0.15 & 0.15 & 0.15 & 0.15 \\
\hline Hemicell & $\%$ & 0.035 & - & - & 0.035 & 0.35 \\
\hline Avemix P $5000^{* *}$ & $\%$ & 0.01 & 0.01 & 0.01 & 0.01 & 0.01 \\
\hline Total & $\%$ & 100 & 100 & 100 & 100 & 100 \\
\hline Chemical composition & Units & A & $\mathrm{B}$ & $\mathrm{C}$ & $\mathrm{D}$ & $\mathrm{E}$ \\
\hline $\mathrm{ME}$ & ( Kcal $\backslash \mathrm{Kg}$ diet & 3223 & 3222 & 3228 & 3288 & 3224 \\
\hline $\mathrm{CP}$ & $\%$ & 19 & 19 & 18.98 & 18.99 & 19 \\
\hline $\mathrm{CF}$ & $\%$ & 3.56 & 3.57 & 3.98 & 3.97 & 4.39 \\
\hline Lysine & $\%$ & 1.1 & 1.1 & 1.1 & 1.1 & 1.1 \\
\hline Methionine & $\%$ & 0.53 & 0.53 & 0.52 & 0.53 & 0.53 \\
\hline Methionine + cysteine & $\%$ & 0.78 & 0.77 & 0.77 & 0.78 & 0.77 \\
\hline Threonine & $\%$ & 0.76 & 0.76 & 0.76 & 0.76 & 0.76 \\
\hline Calcium & $\%$ & 0.86 & 0.86 & 0.84 & 0.85 & 0.85 \\
\hline Available phosphorus & $\%$ & 0.42 & 0.42 & 0.42 & 0.42 & 0.42 \\
\hline Sodium & $\%$ & 0.17 & 0.17 & 0.17 & 0.17 & 0.17 \\
\hline Chloride & $\%$ & 0.22 & 0.22 & 0.22 & 0.22 & 0.22 \\
\hline Potassium & $\%$ & 0.87 & 0.73 & 0.71 & 0.85 & 0.83 \\
\hline
\end{tabular}

*Vitamin-mineral mixture was composed of: Each $3 \mathrm{~kg}$ contain: Vit. A $12000000 \mathrm{IU}$, vit. D3 2000000 IU, vit. E $10000 \mathrm{mg}$, vit. K3 $2000 \mathrm{mg}$, vit B11000 mg, vit. B2 $5000 \mathrm{mg}$, vit B6 $1500 \mathrm{mg}$, vit. B12 10 $\mathrm{mg}$, Biotin $50 \mathrm{mg}$, pantothenic acid $10000 \mathrm{mg}$, Nicotinic acid $30000 \mathrm{mg}$, Folic acid $1000 \mathrm{mg}$, Manganese $60000 \mathrm{mg}$, Zinc $50000 \mathrm{mg}$, Iron $30000 \mathrm{mg}$, Copper $10000 \mathrm{mg}$, Iodine $1000 \mathrm{mg}$, Selenium $100 \mathrm{mg}$, Cobalt $100 \mathrm{mg}$, carrier (CaCo3) add to $3 \mathrm{~kg}$. **Phytase: - (Avemix P5000) was used as feed additive for poultry at a rate of $0.10 \mathrm{~g} / \mathrm{Kg}$. 
containing enzyme showed high value when compared with groups (B and $\mathrm{C}$ ) that received SFM 2.5, 5\% without enzyme and control one. FCR from the obtained data showed that there was non-significant difference in feed conversion ratio (FCR) between all dietary treatment and control group during experimental period from (035) day. However, groups received SFM $2.5 \%$ with or without enzyme showed improvement than others. Hematological parameters included erythrogram was shown at Table (5). The results indicated that there was significant $(\mathrm{P} \leq 0.05)$ increase in $\mathrm{Hb}(\mathrm{g} / \mathrm{dl})$ contents in groups $\mathrm{B}, \mathrm{C}, \mathrm{D}$ and $\mathrm{E}$ when compared with control group. Moreover, group $\mathrm{C}$ showed the highest value than other groups. RBCs count showed significant changes between groups when compared with control one, but there was non-significant difference between $\mathrm{B}$ and $\mathrm{C}$ that received (SFM 2.5, 5\%, respectively). Also, there was nonsignificant difference between $\mathrm{D}$ and $\mathrm{E}$ that received (SFM2.5, 5\% with Hemicell, respectively). $\mathrm{PCV} \%$ and $\mathrm{MCV}$ (fl) showed significant $(p \leq 0.05)$ increase in groups $(B$, $\mathrm{C}, \mathrm{D}$ and $\mathrm{E}$ ) that received (SFM 2.5, 5\%, $2.5 \%+$ Hemicell and SFM 5\%+Hemicell, respectively) when compared with control group. There were significant $(\mathrm{p} \leq 0.05)$ increase in $\mathrm{MCH}(\mathrm{pg})$ and $\mathrm{MCHC}(\%)$ in group contain SFM 5\%+Hemicell when compared with other groups and control one. The effect of dietary treatments on leukogram was shown at Table (6). WBCs count results indicated that there was nonsignificant difference between control group and other groups. While there was significant $(p \leq 0.05)$ difference between B and $\mathrm{E}$ groups that received (SFM2.5, SFM5\%+ Hemicell, respectively). While differential leukocytic count showed that there were non-significant difference in heterophile, lymphocyte, eosinophile and basophile percent between groups with the exception of monocyte $\%$ in which there was significant $(\mathrm{p} \leq 0.05)$ decrease in group received SFM5\%+Hemicell when compared with group received
SFM2.5\%, While other groups showed nonsignificant changes.

\section{DISCUSSION}

Feed intake in SFM5\%+Hemicell group recorded the highest value followed by SFM2.5\% +Hemicell than other groups and controlled one. Generally, the statistical analysis indicates there was no any significant difference between all groups in total feed intake. This may be attributed to the balanced diet offered to all groups. These results were in agreement with those obtained by Horvatovic et al., (2015) who reported that neither SFM nor enzyme supplementation had any effect on feed consumption. Moreover, Furlan et al., (2001) found non-significant difference in feed intake for the starter and grower phases or total experimental period with the dietary addition of sunflower meal. Sunflower meal up to $15 \%$ can be included in broiler feeds with no effect on performance.

Data concerning BWG showed that the best weight gain obtained from groups B and D which fed on SFM 2.5\%, SFM $2.5 \%+$ Hemicell, respectively. The addition of Hemicell ${ }^{\circledR}$ enzyme was not justified, because chickens in the treatments where enzymes were added did not show improvement in performance over chickens in treatments not contained enzymes. Generally, the only apparent disadvantage of sunflower meal is that it contains relatively high level of fiber and low level of metabolizable energy and lysine compared to soybean meal according to NRC (1994). This characteristic of sunflower meal may lead to bulky diets which may be a problem for young chicks, in particular, because their digestive system has a limited capacity. The sunflower meal incorporated at high inclusion rate $(5 \%)$, nutrient and energy densities of the resulting diet may be significantly diluted and growth retarded. This finding agree with Arash (2013) who reported that supplementation diet with Hemicell at the 
Table (4): Effects of different dietary SFM levels with or without $\left(\right.$ Hemicell $\left.{ }^{\circledR}\right)$ enzyme supplementation on broiler chick performance (means $\pm \mathrm{SE}$ ).

\begin{tabular}{lccccc}
\hline \multirow{2}{*}{ Items } & \multicolumn{5}{c}{ The experimental groups } \\
& $\mathrm{A}$ & $\mathrm{B}$ & $\mathrm{C}$ & $\mathrm{D}$ & $\mathrm{E}$ \\
\hline \multirow{2}{*}{ Final body weight gain $(\mathrm{g})$} & 1765.9 & 1953.5 & 1833.5 & 1954.1 & 1777.6 \\
& $\pm 98.29^{\mathrm{a}}$ & $\pm 40.53^{\mathrm{a}}$ & $\pm 122.38^{\mathrm{a}}$ & $\pm 64.46^{\mathrm{a}}$ & $\pm 23.6^{\mathrm{a}}$ \\
Feed intake $(\mathrm{g})$ & 3052.3 & 3189.2 & 3169.8 & 3215.7 & 3235.5 \\
& $\pm 69.35^{\mathrm{a}}$ & $\pm 46.99^{\mathrm{a}}$ & $\pm 87.52^{\mathrm{a}}$ & $\pm 49.12^{\mathrm{a}}$ & $\pm 45.34^{\mathrm{a}}$ \\
Feed conversion ratio & 1.73 & 1.64 & 1.74 & 1.65 & 1.82 \\
& $\pm 0.06^{\mathrm{a}}$ & $\pm 0.06^{\mathrm{a}}$ & $\pm 0.08^{\mathrm{a}}$ & $\pm 0.07^{\mathrm{a}}$ & $\pm 0.01^{\mathrm{a}}$ \\
\hline
\end{tabular}

Means with different letters at the same column differ significantly at $(\mathrm{P} \leq 0.05)$.

Table (5): The effects of different dietary SFM levels with or without (Hemicell $^{\circledR}$ ) enzyme supplementation on erythrogram of broiler chicks (mean $\pm \mathrm{SE}$ ).

\begin{tabular}{cccccc}
\hline \multirow{2}{*}{ Items } & \multicolumn{5}{c}{ The experimental groups } \\
& $\mathrm{A}$ & $\mathrm{B}$ & $\mathrm{C}$ & $\mathrm{D}$ & $\mathrm{E}$ \\
\hline $\mathrm{Hb}(\mathrm{g} / \mathrm{dl})$ & 9.14 & 10.60 & 11.00 & 10.44 & 10.60 \\
$\mathrm{RBCS}$ & $\pm 0.07^{\mathrm{c}}$ & $\pm 0.11^{\mathrm{b}}$ & $\pm 0.04^{\mathrm{a}}$ & $\pm 0.05^{\mathrm{b}}$ & $\pm 0.07^{\mathrm{b}}$ \\
$\left.\times 10^{6 / \mu l}\right)$ & 2.17 & 2.46 & 2.44 & 2.29 & 2.26 \\
$\mathrm{PCV}$ & $28.03^{\mathrm{c}}$ & $\pm 0.04^{\mathrm{a}}$ & $\pm 0.02^{\mathrm{a}}$ & $\pm 0.02^{\mathrm{b}}$ & $\pm 0.02^{\mathrm{b}}$ \\
$(\%)$ & 33.20 & 34.20 & 32.10 & 30.00 \\
$\mathrm{MCV}$ & $129.00^{\mathrm{e}}$ & $\pm 0.20^{\mathrm{b}}$ & $\pm 0.20^{\mathrm{a}}$ & $\pm 0.20^{\mathrm{c}}$ & $\pm 0.32^{\mathrm{d}}$ \\
$(\mathrm{fl})$ & $\pm 1.95^{\mathrm{c}}$ & 135.22 & 140.21 & 140.63 & 132.76 \\
$\mathrm{MCH}$ & 42.22 & $43.27^{\mathrm{b}}$ & $\pm 1.67^{\mathrm{a}}$ & $\pm 0.69^{\mathrm{a}}$ & $\pm 1.37^{\mathrm{bc}}$ \\
$(\mathrm{pg})$ & $\pm 0.39^{\mathrm{c}}$ & $\pm 0.34^{\mathrm{c}}$ & 45.09 & 45.60 & 46.92 \\
$\mathrm{MCHC}$ & 32.64 & 31.93 & $\pm 0.20^{\mathrm{b}}$ & $\pm 0.20^{\mathrm{b}}$ & $\pm 0.63^{\mathrm{a}}$ \\
$(\%)$ & $\pm 0.27^{\mathrm{b}}$ & $\pm 0.34^{\mathrm{b}}$ & 32.17 & 32.42 & 35.34 \\
\hline
\end{tabular}

Means with different letters at the same column differ significantly at $(\mathrm{P} \leq 0.05)$.

Table (6): The effects of different dietary SFM levels with or without (Hemicell $^{\circledR}$ ) enzyme supplementation on leukocytic and differential leukocytic parameters of broiler chicks (mean $\pm \mathrm{SE}$ ).

\begin{tabular}{cccccc}
\hline Items & \multicolumn{5}{c}{ The experimental groups } \\
& $\mathrm{A}$ & $\mathrm{B}$ & $\mathrm{C}$ & $\mathrm{D}$ & $\mathrm{E}$ \\
\hline \multirow{2}{*}{ WBCS $\times 10^{3}$} & 1.92 & 2.06 & 1.88 & 2.02 & 1.82 \\
& $\pm 0.09^{\mathrm{ab}}$ & $\pm 0.10^{\mathrm{a}}$ & $\pm 0.04^{\mathrm{ab}}$ & $\pm 0.04^{\mathrm{ab}}$ & $\pm 0.07^{\mathrm{b}}$ \\
& 26.40 & 24.20 & 33.60 & $24.80 \pm 2.48^{\mathrm{a}}$ & 33.00 \\
Heterophile \% & $\pm 2.36^{\mathrm{a}}$ & $\pm 4.67^{\mathrm{a}}$ & $\pm 6.93^{\mathrm{a}}$ & & $\pm 2.61^{\mathrm{a}}$ \\
& 66.00 & 66.40 & 59.00 & 69.60 & 61.60 \\
Lymphocyte \% & $\pm 1.76^{\mathrm{a}}$ & $\pm 4.93^{\mathrm{a}}$ & $\pm 7.12^{\mathrm{a}}$ & $\pm 2.77^{\mathrm{a}}$ & $\pm 2.32^{\mathrm{a}}$ \\
& 4.00 & 5.20 & 4.60 & 3.80 & 3.20 \\
Monocyte \% & $\pm .84^{\mathrm{ab}}$ & $\pm 0.49^{\mathrm{a}}$ & $\pm 0.51^{\mathrm{ab}}$ & $\pm 0.58^{\mathrm{ab}}$ & $\pm 0.49^{\mathrm{b}}$ \\
& 1.60 & 2.20 & 2.80 & 1.40 & 2.20 \\
Eosinophile \% & $\pm 0.40^{\mathrm{a}}$ & $\pm 0.37^{\mathrm{a}}$ & $\pm 0.73^{\mathrm{a}}$ & $\pm 0.51^{\mathrm{a}}$ & $\pm 0.49^{\mathrm{a}}$ \\
& 00.00 & 00.00 & 00.00 & 00.00 & 00.00 \\
Basophile \% & $\pm 0.00^{\mathrm{a}}$ & $\pm 0.00^{\mathrm{a}}$ & $\pm 0.00^{\mathrm{a}}$ & $\pm 0.00^{\mathrm{a}}$ & $\pm 0.00^{\mathrm{a}}$ \\
\hline
\end{tabular}

Means with different letters at the same column differ significantly at $(P \leq 0.05)$. 
levels 0.05 or $0.1(\mathrm{~g} / \mathrm{kg})$ during the starter phase, grower phase and the course of study, body weight gain, feed intake and feed conversion ratio (FCR) did not significantly differ among the treatments. Also, the results was agreement with Ravindran et al., (1999) who did not find any beneficial effects on production performance of broiler chickens when they were fed with cereal-based diets (corn, wheat or barely) supplemented with xylanase. The results confirmed by Meng and Slominski (2005) and Tabook et al., (2006) who reported that the addition of commercially available multiactivity enzyme products did not result in improved broiler performance in diets especially having increased concentration of SFM. Results were in agreement with Mandal et al., (2003) who showed that inclusion of undecorticated SFM at 0,50 and $100 \mathrm{~g} / \mathrm{kg}$ in broiler chicken diets replacing part of SBM had no significant impact on weight gain. In contrast, Mutassim and Fuad (2007) and Peric et al., (2010) concluded that the inclusion of SFM resulted in worse broiler performance which discussed by Hesselman and Aman (1986) who stated that $\beta$-glucans adversely affect all nutrients, especially protein and starch utilization and are known to give rise to highly viscous conditions in the small intestine of the chicks. Data concerning FCR showed that groups received SFM $2.5 \%$ with or without enzyme showed improvement than others. This improvement may be attributed to the higher final body weight. These results supported by Mutassim and Fuad (2007) who reported that adding different levels of SFM; 0, 5, 10, and 15\% with and without ß-Glucanase Enzyme (E) to broiler starter and finisher rations, had no significant effect on feed conversion ratio (FCR). Also, Ibrahim and El-Zubeir (1991) found that feed conversion efficiency of broiler chickens were similar in all investigated groups contained up to $30 \%$ SFM. Moreover, some researchers found that the highest level sunflower meal inclusion
$(20 \%)$ in the diet improved feed conversion ratio which was explained by the fact that the oil inclusion level was increased in order to supply birds' energy needs Tavernari et al., (2008).Data concerning erythrogram showed that groups received SFM at 2.5 and $5 \%$ with or without enzyme supplementation showed significant $(p \leq 0.05)$ increase in $\mathrm{Hb}, \mathrm{RBCs}$ and PCV levels when compared with control group, similar to finding of Haddadin et al., (1996) who found that addition of esterified glucomannan to broilers diet is significantly increases RBCs count. The most likely explanation was the improvement of bioavailability of essential nutrients. One of most powerful hypothesis about RBCs increase is due to beta- glucan existence. As revealed by Selvaraj et al., (2005) on common carp (C. carpio), betaglucan (especially beta 1-3 glucan) is an immunity stimulant for animals Sinha et al., (2011). So glucan residues would cause the WBCs and maybe RBCs production. From obtained results that related to leukogram revealed that WBCs decrease by increase SFM level, and this finding agrees with Fasuyi et al., (2013) who found that the white blood cells (WBC) count values from blood samples of pigs were significantly $(p \leq 0.05)$ increased by the increase levels of Tithonia diversifolia (wildsunflower) leaf meal (TDLM) reported that neutrophils and monocytes were not significant affected when the levels of TDLM increased in dietary treatments. While, Selvaraj et al., (2004) who stated that inclusion of different levels of full-fat SFS in broiler diets, not statistically effect on blood parameters of poultry.

From the results of current study we can conclude that the addition of Hemicell ${ }^{\circledR}$ enzyme at $0.35 \mathrm{~kg} / \mathrm{ton}$ was not justified, because chickens in the treatments where enzymes were added did not show improvement in performance over chickens in treatments not contained enzymes. The inclusion level $2.5 \%$ of sunflower meal had a positive a role in improved final body 
weight gain comparing with other treatment groups. Partial replacement diet with sunflower meals (2.5 and 5\% with or without Hemicell ${ }^{\mathbb{R}}$ ) did not induce side effects on hematological parameters.

\section{REFERENCES}

Acamovic, T. 2001. Enzymes for poultry. World's Poult. Sci. J, 57: 225-242.

Arash Azarfar. 2013. Effect of hemicell enzyme on the performance, growth parameter, some blood factors and ileal digestibility of broiler chickens fed corn/soybean-based diets. J. Cell Anim. Biol. 7(7): 85-91.

Duncan, (SPSS program Version 10.0.7, June). 2000. ANOVA, (Analysis of variance), LSD (Least Significant Difference) and multiple range tests. Res., 28: 65-74. Biometrics, 11: 142.

Fasuyi, A.O., Ibitayo, F.J., Alo, S.O. 2013. Histopathology, Haematology and Serum chemistry of growing pigs fed varying levels of wild sunflower (Tithonia diversifolia) leaf meal as protein supplements. IOSR Journal of Agriculture and Veterinary Science (IOSR-JAVS). 4(1): 41-50.

Furlan, A.C., Mantovani, C., Murakami, A.E., Moreira, I., Scapinello, C., Martins, E.N. 2001. Use of sunflower meal in broiler chicks feeding. Rev. Bras. Zootec, 30: 158-164.

Haddadin, M. S., Abdulrhim, S. M., Hashlamoun, E. A., Robinson, R. K. 1996. The effect of lactobaculls acidophilus on the production and chemical composition of hen's eggs. Poultry science, 75: $491-494$.

Hesselman, K., Aman, P. 1986. The effect of $\beta$ - glucanase on the utilization of starch .and nitrogen by the broiler chickens fed on barley of low .and high viscosity. Anim. Feed Sci. Technol, 15: 83-93.

Horvatovic, M.P., Glamocic, D., Zikic, D., Hadnadjev, T.D. 2015. Performance and Some Intestinal Functions of Broilers Fed Diets with Different
Inclusion Levels of Sunflower Meal and Supplemented or Not with Enzymes. Brazilian Journal of Poultry Science, 17 (1): 25-30.

Ibrahim, M.A., Zubeir, E.A.E. 1991. Higher fibre sunflower seed meal in broiler chick diets. Animal Feed Science .and Technology, 33: 343-347.

Mahmoud Alagawany., Mayada Ragab Farag., Mohamed Ezzat Abd ElHack., Kuldeep Dhama. 2015. The Practical Application of Sunflower Meal in Poultry Nutrition. Adv. Anim. Vet. Sci, 3(12): 634-648.

Meng, X., Slominski, B.A. 2005. Nutritive values of corn, soybean meal, canola meal and peas for broiler chickens as affected by a multicarbohydrase preparation of cell wall degrading enzymes. Poult. Sci. 84: 1242-1251.

Mushtaq, T., Sarwar, M., Ahmad, G., Nisa, M.U., Jamil, A. 2006. The influence of exogenous multi-enzymes preparation and graded levels of digestible lysine on the performance of young broiler chicks two weeks post hatching in sunflower meal based diets. Poult. Sci, 85: 2180-2185.

Mutassim Abdelrahman, M., Fuad Saleh, H. 2007. Performance of Broiler Chickens Fed on Corn- Sunflower Meal Diets with B- Glucanase Enzyme. Jordan Journal of Agricultural Sciences, 3(3): 272-279.

NRC. 1994. National Research Council. Nutrient Requirement for Poultry. Ninth Revised Ed. National Academy Press, USA.

Peric, L., Milic, D., Bjedov, S. 2010. The effect of sunflower meal on growth performance of broiler chicks. Proceedings of the 13th European Poultry Conference, Tours. France.

Ravindran, V., sSelle, P.H., Bryden, W.L. 1999. Effects of phytase supplementation individually and in combination with glycanase on nutritive value of wheat and Barley. Poult. Sci, 78: 1588-1595. 
Selvaraj, R.K., Purushothaman, M.R. 2004. Nutritive value of full-fat sunflower seeds in broiler diets. Poult. Sci, 83: 441-446.

Selvaraj, V., Sampath, K., Sekar, V. 2005. Administration of yeast glucan enhances survival and some nonspecific and specific immune parameters in carp (Cyprinuscarpio) infected with Aeromonas hydrophila. Fish Shellfish Immunol. 19(4): 293306.

Sinha, A.K. Kumar,V., Makkar, H.P.S., De Boeck, G., Becker, K. 2011. Nonstarch Polysaccharides and their role in fish Nutrition. Rev. Food Chem. 127(4): 1409-1426.

Tabook, N.M., Kadim, I.T., Mahgoub, O., Al-Marzooqi, W. 2006. The Effect of Date Fibre Supplemented With an Exogenous Enzyme on the Performance and Meat Quality of Broiler Chickens. Br. J. Poult. Sci, 47: 73-82.

Tavernari, F. C., Albino, L. F. T., Morata, R. L., Dutra Júnior, W. M., Rostagno, H. S., Viana, M. T. S. 2008. Inclusion of sunflower meal with or without enzyme supplementation in broiler diets. Brazilian Journal of Poultry Science, 10: $233-238$. 